\title{
Self Disclosure Pengguna Bottled di Wilayah Jakarta
}

\author{
Evelyn Natasha, Septia Winduwati \\ beatrixeen@gmail.com, septiaw@fikom.untar.ac.id \\ Fakultas Ilmu Komunikasi Universitas Tarumanagara
}

\begin{abstract}
Bottled users' self-disclosure is the occurrence by writing the contents of the heart and feelings about various things as well as statements that are sometimes unable to be discussed like things that are intimately or private when announced on general media, not anonymous. The purpose of determining how self-disclosure of anonymous social media users named Bottled. This research uses self-disclosure theory (Johari Window) and social penetration theory. This research uses a qualitative approach with the method used is a case study. Database collection technically with interviews, observation, and documentation. The key information this study were Psychologists as expert speakers and three supporting informants who were found through purposive sampling techniques.This study results reveal that self-disclosure that occurs in Bottled users makes individuals more comfortable to be open about evaluative and descriptive expressions. Bottled users' self-disclosure is also a form of self-clarification.
\end{abstract}

Keywords: anonymous media, interpersonal communication, self disclosure, social media.

\begin{abstract}
Abstrak
Self disclosure pengguna Bottled ini merupakan terjadinya suatu tindakan pengungkapan diri menggunakan menuliskan isi hati dan perasaan tentang berbagai macam hal serta pernyataanpernyataan yang terkadang mampu dibicarakan misalnya hal yang bersifat intim atau terlalu privasi bila dibagikan pada media yang terlalu generik, yang bukan anonim. Penelitian ini bertujuan buat mengetahui bagaimana self-disclosure pengguna media umum anonim bernama Bottled. Penelitian ini menggunakan teori a (Johari Window) \& teori penetrasi sosial. Penelitian ini memakai pendekatan kualitatif menggunakan metode yang digunakan merupakan studi perkara. Teknik pengumpulan data menggunakan wawancara, observasi dan dokumentasi. Narasumber dalam penelitian ini adalah Psikolog menjadi narasumber pakar dan tiga informan pendukung yang ditemukan melalui teknik purposive sampling. Hasil penelitian ini mengungkapkan bahwa self disclosure yang terjadi pada pengguna Bottled berakibat individua lebih nyamana untuk terbukaa tentang ungkapan yang evaluatif $\&$ naratif. Self disclosure pengguna Bottled pula sebagai bentuk penjernihan diri.
\end{abstract}

Kata Kunci : komunikasi antarpribadi, media anonim, media sosial, self disclosure.

\section{Pendahuluan}

Menurut Joseph A. Devito (2011) pengiriman pesan baik secara verbal juga non-verbal antara 2 orang atau lebih yang saling mempengaruhi bisa didefinisikan menjadi komunikasi interpersonal. Melalui komunikasi kepada orang lain, kita ternyata bisa memenuhi kebutuhan emosional dan intelektual kita. Kebutuhan emosional \& intelektual kita itu ternyata pada peroleh pertama kali berasal menurut keluarga, lalu dari orang - orang dekat misalnya kerabat dan kawan- kawan, baru masyarakat umum termasuk di dalamnya merupakan sekolah \& media massa misalnya surat kabar dan televisi. 
Menurut McQuail (2011) dengan bantuan teknologi misalnya aplikasi membuatkan pesan juga sosial media lainnya membangun perubahan pola konduite komunikasi generasi millenial. Lantaran komunikasi interpersonal tatap muka kini ini sanggup dibilang intensitasnya rendah jika dibandingkan menggunakan komunikasi pada dunia maya. Penyingkapan diri juga merupakan tindakan yang berisiko, antara lain mencakup risiko personal, resiko berhasil, dan resiko profesional (Widiyana, 2015). Kehadiran teknologi baru, khususnya internet, membarui tuntutan penyingkapan diri antar individu. Jika di dalam kehidupan sehari-hari penyingkapan diri adalah tindakan yang cukup berisiko, di pada berkomunikasi melalui internet resiko ini relatif lebih rendah. Dilansir dari detik.com 11 Juni 2019 Aplikasi jejaring sosial universal sebenarnya banyak sekali jenisnya, tetapi yang satu ini dapat dikatakan sangat unik. Bottled mengusung konsep mengirim pesan melalui sebuah botol kaca yang dihanyutkan ke bahari. Jadi, tidak hanya pada dunia nyata saja melainkan pada global virtual pun pengguna dapat melakukannya. Ketika pesan tadi telah dikirimkan menggunakan cara dihanyutkan ke laut impian, nantinya akan terdapat orang lain yang dapat mendapat pesan itu. Lalu, orang itu bisa tetapkan antara mau disimpan saja atau malah memulai chat. Mengingat bahwa komunikasi interpersonal di era digital itu penting, lantaran kehadiran teknologi menciptakan kajian komunikasi menjadi luas \& poly makna yang harus dipelajari kembali galat satunya seperti penyingkapan diri. Maka penelitian ini bermaksud untuk mendeskripsikan bagaimana terjadinya self disclosure pada antara pengguna aplikasi menyebarkan pesan Bottled.

\section{Metode Penelitian}

Berdasarkan tipe atau jenis riset dalam penelitian ini, dipakai metode penelitian kualitatif. Jenis metode penelitian kualitatif yang dipakai yakni studi kasus. Menurut Susilo Rahardjo \& Gudnanto (2011: 250) studi masalah adalah sebuah metode buat tahu individu yang dilakukan secara integratif dan komprehensif supaya diperoleh pemahaman yang mendalam terhadap individu beserta masalah yang dihadapinya serta tujuan masalahnya dapat terselesaikan \& memperoleh perkembangan diri yang baik. Secara garis besar, teknik yang bisa dipakai buat pengumpulan data pada studi kasus bisa berupa merupakan wawancara, observasi, dan studi dokumentasi. Penelitian ini memakai teknik naratif, bertujuan membuat deskripsi secara sistematis, faktual dan akurat tentang fakta-fakta dan sifat-sifat populasi ataupun objek eksklusif.

\section{Populasi dan Sampel}

Wilayah generalisasi yang terdiri atas subyek atau obyek yang memiliki karakter \& kualitas eksklusif yang ditetapkan oleh seorang peneliti buat dipelajari yang lalu ditarik kesimpulannya dipahami menjadi definisi populasi (2017). Populasi pada penelitian ini memiliki kriteria sebagai berikut :

1. Pengguna media sosial spesifik yang dijadikan penelitian (Bottled)

- Laki-laki atau Perempuan

- Berusia 20-25 tahun

- Aktif menggunakan Bottled minimal 3 bulan

2. Seorang narasumber pakar buat membahas self disclosure di media sosial umum. 
Maka peneliti memilih seluruh informan dalam penelitian ini dengan menggunakan teknik Sampling Purposif (purposive sampling) yakni peneliti menentukan kriteria mengenai responden mana saja yang bisa dipilih sebagai sampel. Para informan primer dipilih menggunakan teknik purposive sampling yang telah peneliti jelaskan sebelumnya. Peneliti menemukan ketiga informan penelitian dari ketersediaan mereka :

\begin{tabular}{llll}
\hline No. & Nama & Jenis Kelamin & Keterangan \\
\hline 1. & Jean Chandra & Laki-laki & Mahasiswa \\
\hline 2. & David Argoanto & Laki-laki & Mahasiswa \\
\hline 4. & Gisela Kurniawan & Perempuan & Mahasiswi \\
\hline
\end{tabular}

Selain informan utama, peneliti disini pula amengambil narasumber pakar sebagai pelengkap penelitian. Informan pendukung dipilih menurut latar belakang yang mempunyai keterkaitan dengan media sosial juga ahli komunikasi yang memiliki pengetahuan mengenai self disclosure. Narasumber ahli ini seorang Psikolog yang juga paham mengenai media sosial atau pernah meneliti media sosial. Peneliti asumsikan bahwa seorang psikolog sanggup menjawab beberapa berita tentang diri pelaku self disclosure pada media sosial umum.

\begin{tabular}{llll}
\hline No. & Nama & Jenis Kelamin & Keterangan \\
\hline 1. & Talissa Carmelia & Perempuan & Psikolog \\
\hline
\end{tabular}

\section{Hasil Penemuan dan Diskusi}

Dari jawaban beberapa informan mengenai fungsi self disclosure, para informan mempunyai alasan yang beragam mengenai fungsi pengungkapan diri tadi. Sehingga bisa disimpulkan bahwa fungsi mereka melakukan self disclosure pada media umum anonim ini yakni sesuai dengan beberapa fungsi menurut Derlega dan Grzelak bahwa pada beberapa surat yang membicarakan diri mempunyai fungsi ekspresi. Dimana menggunakan melakukan pengungkapan diri, seorang bisa menyampaikan aneka macam macam perasaan yang tertuang dalam bentuk surat pada media umum Bottled sehingga bisa dikatakan seorang tadi mendapatkan kesempatan buat mengekspresikan perasaannya. Selain itu juga yang disampaikan oleh beberapa informan tadi memiliki fokus menurut pemahaman fungsi self disclosure lainnya yakni diri individu merasakan kelegaan karena mampu mengeluarkan sesuatu hal yang terjadi dalam dirinya berkaitan menggunakan hal pribadi yang bersifat negatif sekalipun.

Pada kenyataanya output penelitian mengenai tipe kepribadian ini menerangkan adanya individu yang ekstrim ekstrovert maupun ekstrim introvert yang menyebabkan salah satunya akan cenderung sebagai orang yang gampang terbuka, namun yang ada merupakan individu yang memiliki kesamaan ekstrovert dan kesamaan introvert. Artinya faktor kepribadian dari Devito ini tidak selalu berpengaruh pada individu yang melakukan self disclosure lantaran pada intinya seorang akan sebagai ekstrovert waktu terdapat hal yang ingin dibagikan dan hal tadi 
mengandung sesuatu yang membanggakan serta kebalikannya seorang akan menjadi introvert bila topik yang dibicarakan bersifat terlalu eksklusif atau bahkan yang berkaitan konduite jelek seseorang sehingga individu akan cenderung tertutup untuk berbagi pada orang lain.

Menurut narasumber pakar, Talissa beropini bahwa tipe kepribadian akan terbentuk dari faktor bawaan (traits) dan faktor belajar menurut lingkungan. Sehingga jika individu secara bawaan juga termasuk individu yang introvert (tertutup) dengan lingkungan keluarga yang pula tertutup maka konduite individu secara umum pula akan tertutup, baik di kehidupan sehari-hari juga perilakunya pada media umum. Hal ini lantaran konduite seseorang pada dasarnya mencerminkan kepribadiannya. Talissa juga berpendapat bahwa adanya faktor ketertarikan individu terhadap minat mengakses media sosial ini tergantung dalam faktor kepribadian dan tuntutan lingkungan. Seseorang yang bergabung menggunakan lingkungan yang menuntut update dapat mendorong individu buat lebih tak jarang atau terbiasa mengakses media umum. Kemudian bila mereka memiliki alasan buat mengakses media anonim karena mungkin sebagian berdasarkan mereka terdapat yang mempunyai hal yang ini dapat dibagikan secara terbuka dalam media sosial umum.

Media anonim bisa dikatakan juga sebuah media minoritas karena berdasarkan jumlah, media jenis ini poly bermunculan misalnya media umum yang anonim atau pada arti jelasnya media sosial anonim ini lebih poly dan lebih populer menurut dalam media anonim. Dalam penggunaanya ada individu yang memilih media anonim karena identitas yang melekat dalam setiap orang. Sehingga dengan anonim seseorang bisa menentukan buat mengekspresikan bukti diri yang tidak mereka tampilkan secara terbuka pada dunia konkret.

Pada penelitian media anonim ini ditemukan pengaruh yang terlalu ekstrim baik misalnya contoh masalah pada media sosial yang sudah dikemukakan di atas maupun pengaruh berdasarkan teori. Dari ketiga informan penelitian mengaku hal yang dirasakan sehabis melakukan pengungkapan dalam media sosial anonim Bottled diantaranya merupakan mendapat solusi atau masukan dari pengguna anonim lainnya yang terdapat pada kolom komentar mengenai hal yang diungkapkannya tadi, kemudian ada juga yang menerima kenalan baru lantaran meskipun media anonim terdapat saja yang bertukar ID Line atau Instagram, sehingga pengaruh ini menyebabkan terjalin adanya suatu hubungan antarpribadi di luar forum Bottled. Dalam hasil wawancara pada penelitian ini imbas yang peneliti dapatkan adalah kelegaan diri lantaran bisa mengungkapkan perasaan, terjalin komunikasi antarpribadi karena sampai termin menerima kontak yang lebih privasi dan pada surat yang bertema seks bahayanya yakni bisa sampai dalam tahap phone sex atau berlanjut dalam bahasan antarpribadi tentang seks pada ruang yang lebih privasi diluar forum Bottled.

Penelitian ini memakai teori Johari Window yang menyatakan bahwa taraf keterbukaan dan pencerahan tentang diri yang dibagi pada empat bingkai. Keempat bingkai tersebut yakni, ventilasi terbuka (open), ventilasi buta (blind spot), jendela tersembunyi (hidden), dan ventilasi gelap (unknown). Sehingga bila output penelitian ini dikaitkan dengan teori Johari Window yang sudah peneliti bahas sebelumnya yakni terdiri berdasarkan 4 bingkai yang digeser sebagai akibatnya keempat ruang tersebut pada diperbesar atau dikecilkan buat mendeskripsikan self disclosure pada Bottled. Untuk detail berikut gambar Jendela Johari tentang self disclosure pengguna Bottled. 
Gambar 1. Hasil self disclosure pengguna Bottled pada Johari Window

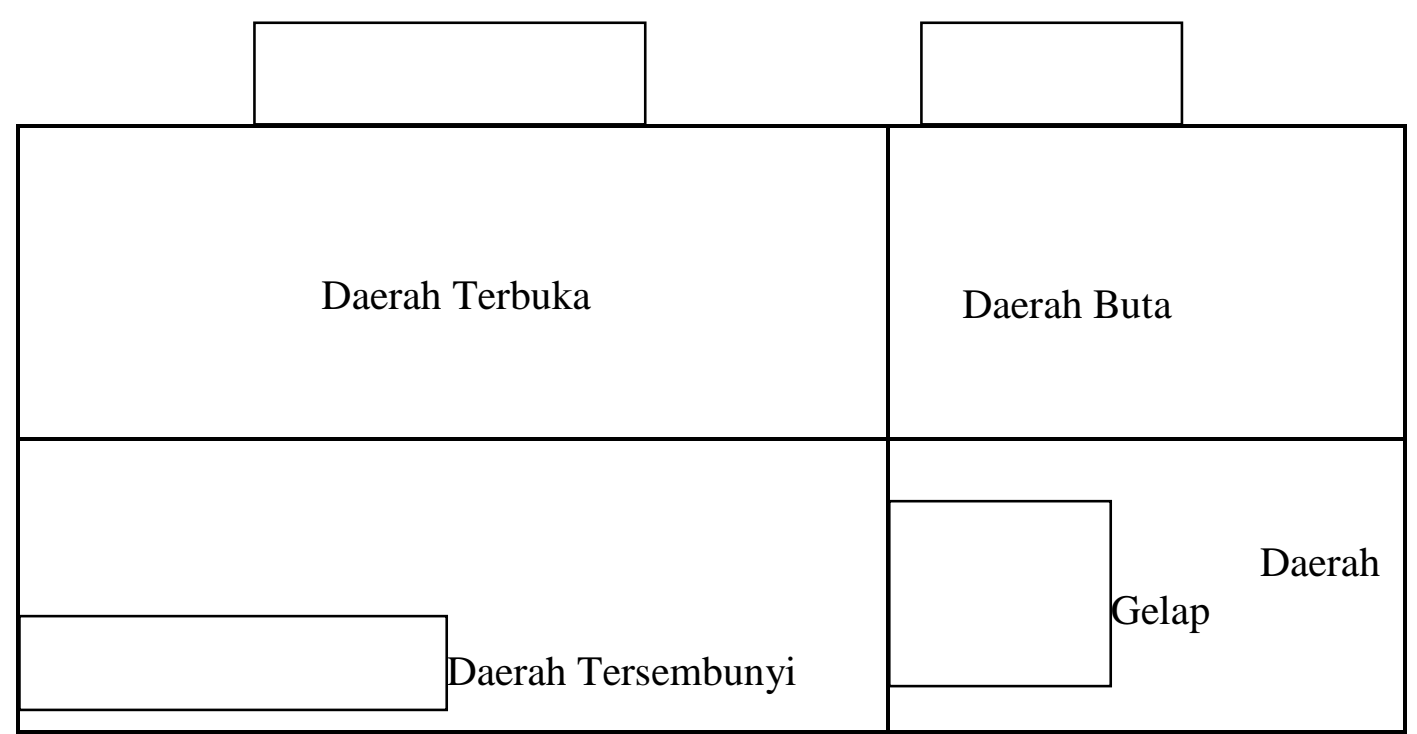

Sumber : Peneliti

Pada gambar di atas, memberitahukan 4 buah bentuk jendela yang memiliki ruang berbeda. Dalam hal ini pada Jendela Tersembunyi (hidden) mempunyai ruang yang lebih akrab dibandingkan menggunakan ketiga ventilasi lainnya. Berikut penjelasannya:

- Open Window ikut terbuka namun tidak sebesar pada daerah tersembunyi hal ini terjadi karena individu sudah berani melakukan penyingkapan diri pada media sosial Bottled sebagai akibatnya keterangan yang dibagikan diketahui oleh orang lain meskipun tetap dalam keadaan anonim.

- Blindspot Window mengecil lantaran pada hal ini self disclosure dalam media anonim antar individu yang saling mengenal, namun tetap ada berita yang diketahui sang pengguna lain yang membaca status pengungkapan diri tersebut.

- Hidden Window terbuka lebih luas, hal ini menandakan bahwa individu yang melakukan self disclosure dalam media umum anonim Bottled memahami dirinya sendiri namun sebaliknya orang lain tidak mengetahui siapa dirinya. Media anonim ini memungkinkan individu terbuka terhadap hal-hal yang dia pahami, yang terkadang bisa bersifat rahasia tetapi waktu hal tersebut dibagikan dalam media anonim, orang lain mengetahui akan hal-hal tersebut sebelumnya dan tetap tidak mengetahui siapa yang melakukan pengungkapan diri tersebut. Dalam jendela tersembunyi ini menurut Budyatna dan Ganiem yang dikutip oleh Chiko pada skripsinya bahwa jendela ini juga memiliki ruang yang luas, ventilasi ini bermuatan semua hal-hal yang kita tahu mengenai diri kita sendiri tetapi orang lain tidak mengetahui diri anda, atau mampu disebut juga dengan rahasia (secret). Jadi mampu disimpulkan bahwa hal-hal yang tidak orang lain ini dibagikan sehingga orang lain mengetahui suatu fakta meskipun menggunakan identitas yang tetap diketahui orang lain ini dibagikan 
sehingga orang lain mengetahui suatu kabar meskipun dengan identitas yang tetap diketahui.

- Unknown Window mengecil tetapi lebih luas berdasarkan daerah buta (blind spot) mengartikan bahwa kedua belah pihak tidak mengenal satu sama lain sebagai akibatnya saat membaca status pengungkapan diri mereka tetap sama-sama mengetahui.

\section{Simpulan}

Berdasarkan pembahasan tentang pengungkapan diri, akan peneliti jabarkan dan simpulkan tentang surat-surat seperti apa saja yang masuk pada kategori self disclosure yang ditemukan pada media anonim Bottled. Dalam proses penyingkapan diri ini peneliti memfokuskan pada pernyataan-pernyataan yang dituliskan sang pengguna Bottled dengan bentuk 'surat' mengenai curhatan hati mereka atau 'curhat'. Mencurahkan isi hati ini peneliti asumsikan sama halnya dengan penyingkapan diri lantaran pada melakukan curhat seseorang akan bercerita dan membuatkan baik secara lisan juga tentang hal-hal yang terjadi pada dirinya. Hal-hal tersebut sanggup berupa sikap atau pendapat yang diungkapkan, tentang selera dan minat seseorang terhadap suatu hal, pekerjaan atau pendidikan seseorang, pernyataan tentang fisik, masalah finansial, atau tentang kepribadian.

Berdasarkan uraian - uraian dari pembahasan pada bab sebelumnya maka bisa peneliti simpulkan beberapa hal mengenai menggunakan self disclosure pada media umum Bottled menjadi berikut :

1. Self disclosure pada media anonim membuahkan informan lebih nyaman untuk terbuka tentang beberapa hal yang dimulai dari ungkapan yang sifatnya naratif atau hal-hal generik misalnya insiden sehari-hari yang terjadi dalam dirinya sampai ungkapan yang evaluatif atau ungkapan-ungkapan yang lebih intim dengan identitasnya yang tetap tidak diketahui pengguna lain.

2. Self disclosure yang terjadi pada informan di media umum Bottled yakni menjadi bentuk penjernihan diri lantaran surat-surat tersebut memberikan kesempatan buat mengungkapkan hal yang dianggap rahasia kini sebagai terbuka sampai individu setidaknya melepaskan sesuatu hal yang dirasakan sampai membentuk suatu penjernihan bagi diri individu. Manfaat sosial ini terlihat ketika individu menjadi anonim justru berani menuliskan surat tentang

\section{Implikasi} dirinya yang mampu diungkapkan dalam media umum beridentitas.

Media anonim misalnya Bottled sebagai tempat terjadinya self disclosure atau penyingkapan diri mulai mencurahkan isi hati sampai menjadi loka penjernihan diri penggunanya. Fungsi sosial ini terlihat waktu informan menjadi anonim justru berani menceritakan surat mengenai diri sendiri yang bisa dipublikasikan dalam media sosial beridentitas. Dampak yang dirasakan yakni menerima komentar dan surat balasan yang mendukung ataupun malah sebaliknya yang merugikan. Artinya dampak yang dirasakan tergantung bagaimana individu dari yang mendukung, ada yang memberi masukan, sampai balasan yang menyenangkan. 


\section{Ucapan Terima Kasih}

Penulis mengucapkan terima kasih kepada Fakultas Ilmu Komunikasi Universitas Tarumanagara yang telah menaruh tugas buat pembuatan jurnal ini, dan kepada semua informan yang bersedia diwawancarai untuk penelitian.

\section{Daftar Pustaka}

Deddy Mulyana. (2017). Ilmu Komunikasi Suatu Pengantar. Jakarta: Remaja Rosda Karya.

Devito. J. A. (2011.) Komunikasi Antar Manusia Edisi Kelima. Tangerang Selatan: Karisma Publishing Group.

Kriyantono, Rachmat. (2013). Riset Komunikasi. Jakarta: Kencana Prenada Media Group.

Liliweri, A. (2011). Komunikasi Antar Pribadi. Bandung : PT Citra Adya Bakti.

McQuail, Denis. (2012). Teori Komunikasi Massa Edisi 6. Jakarta: Salemba Humanika.

Moleong, Lexy J. (2014). Metodologi Penelitian Kualitatif. Bandung: Remaja Rosda Karya.

Rakhmat, Jalaluddin. (2007). Psikologi Komunikasi. Bandung: Remaja Rosda Karya. 